\title{
Social Capital Analysis on Agribusiness Microfinance Institution Performance
}

\author{
Amalia Nur Milla \\ Agribusiness Department, Agriculture Faculty, Universitas Muhammadiyah Sukabumi \\ E-mail: amalia.nurmilla@ummi.ac.id
}

\begin{abstract}
The purposes of this research to look at the social capital and Agribusiness Microfinance Institution Performance (LKMA) that owned by Gapoktan beneficiary Rural Agribusiness Development Program (PUAP) in Sukabumi City. The kind of this research is survey research with the qualitative method. The primary data used key informant by interviewed and secondary data get from institution and literature as the relevant in this research. Data processing was done descriptively to describe the social capital and LKMA performance. The result of this research showed social capital problems, as followed: 1) Gapoktan member adherence to the agreement (the norms/rules), especially for a refund, 2) Less of a sense of responsibility (confidence/trust), 3) Less of communication and cooperation (networking). Based on the social capital analyze, there are three categories of LKMA performance, there are LKMA well performing, worse and problematic performing. Strengthen of social capital to improve LKMA performance to solve their problems.
\end{abstract}

Keywords: Social capital, LKMA performance, rural agribusiness development program

\section{INTRODUCTION}

Since 2008-2015 the Ministry of Agriculture has implemented rural agribusiness development program (PUAP) which is a program aimed at reducing poverty and unemployment that are focused to accelerate the development of the productive economy in rural areas farmers cultivated. PUAP is one of the poverty reduction program that aims to solve the fundamental problems faced by farmers is the lack of access to sources of capital, markets and technology and farmer organizations are still weak. The program is implemented by the combined farmer's institution (Gapoktan) as executor PUAP program that is expected to carry out institutional functions rural economy by growing the Institute of Economics of Microfinance (MFI-A) as one of the business units that manage and serve the financing for the farmers who are members of Business agribusiness farmers through PUAP program it is necessary to be successful. In practice Gapoktan PUAP get financial assistance amounting to 100 million as a revolving fund for productive economic activities of farmer group union members.

Agricultural development through PUAP particular program should be able to achieve the aim to alleviate poverty and the welfare of farmers. Some experts elaborates on the concept of social capital in relation to development, economic and political. One of them stated that the existence of social capital (social capital) can be seen from the ability of a community to make a set of rules or norms or used (rules in use) which is used as a reference for action is a prerequisite for the success of development projects [1]. The concept of social capital is an aspect of the structure of relationships between individuals that can create new values [2]. Social capital refers to the main aspects of social organization that confidence (trust), norms (norms) and cooperation / networks (networks) are the main elements of the construction of a social community (civic community). Social capital can also increase the efficiency of a society by facilitating the coordinated actions [3]. Social capital is now starting to be recognized as a good resource that can facilitate or can hinder social action (process development), social capital is a social energy that can be harnessed for development [4].

In addition, the current agricultural development cannot be separated from the paradigm of agribusiness. Agribusiness is considered as a new perspective on agriculture-oriented optimization of resource utilization for the welfare of mankind. According in Situmorang's dissertation research states that information, mutual trust and cooperation in kelompok tani is essential to the success of social capital PUAP program. Therefore, the success of agribusiness farmers in PUAP program requires farmers a good social capital, as well as the performance of gapoktan very important as an institution that is a forum for farmers. In this case the performance of Microfinance Institutions a unit from the Group, which manages the funds PUAP [5].

One of the areas that get PUAP program since 2008 is the city of Sukabumi which is the transition area between the village and the town is now an urban area. The urban area is presumably have social capital began to fade, so interesting to study. Based on the above, the research on Social Capital Analysis on Performance of Microfinance Institutions in the city of Sukabumi is important to do.

\section{LITERATURE REVIEW}

Social capital shows on networks, norms and trust that the potential productivity of society. However, social capital in contrast to financial capital, because of social capital are cumulative and grow by itself (self-reinforcing). Therefore, social capital will not be depleted if used, but increasing. The destruction of social capital is more often caused not by use, but because it is not used [1]

Social capital can be defined simply as an instantiated set of informal values or norms shared among members of a group that permits them to corporate with one another." Social capital is simply defined as a set of values grades or informal norms 
spontaneously divided among the members of a group that allows the establishment of cooperation between them. Fukuyama argued that they should lead to cooperation in groups and are associated with such traditional virtues: honesty; committed; responsible work and norms of mutual reciprocity. Furthermore, described by Fukuyama that under certain conditions of social capital can facilitate community degree of innovation and adaptability of the community. Unlike the human capital, social capital also refers to the ability of people to associate with others. Relying on norms and values, association between humans produces confidence, which in turn has a significant economic value and measurable. Related to this, there are three parameters of social capital, is the confidence (trust), norms (norms) and networks (networks). [6]

Social capital is defined by its function not as a manifestation of a single but a wide variety of different form with two common elements; (1) social capital consists of several aspects of the social structure and (2) social capital facilitates certain actions either an individual or a few individuals within the structure. Aspects of social structure into the concept of social capital are the elements: liability (obligation), hope (expectation), confidence (trustworthiness), channel information (information channel), norms and sanctions. [2]

Institutional development is one of the basic components in the overall design of Revitalization of Agriculture, Fisheries and Forestry (RPPK) 2005-2025. During this institutional approach has also been a central component in the development of agriculture and rural areas. In an effort to empower farmers in rural areas, the central government through the Ministry of Agriculture to implement various programs in the field of technological innovation, development of agribusiness, capital, and so on. One of the programs initiated by the Ministry of Agriculture to implement the empowerment of farmers in agribusiness in rural areas is the Rural Agribusiness Development Program (PUAP). Institutional farmers get PUAP program which Farmers Group, hereinafter referred gapoktan is a collection of some farmer's group join and work together to improve economies of scale and operational efficiency. Gapoktan achievement is gapoktan that have high performance and productivity, and success in implementing and developing the functions and strengthen institutions, improve the income and welfare of its members.

The ability of a person's performance in quality and quantity in performWorks performance or also called the performance can be defined as the achievement of results [6]. Performance can also be regarded as a work behaviour, appearance, or works. Because it is a form of multidimensional performance, so how to measure it varies greatly depending on many factors. It is almost the same as the Mangkunagara's defines "performance (performance) is the result of the quality and quantity of work achieved by someone employee in performing their duties in accordance with the responsibilities given to him".[7] A person's performance is a combination of capabilities, businesses and opportunities that can be judged from their work.[8] To measure performance, success, and achievement farmer group in carrying out its functions need to be carried out an assessment of the combined group of farmers who have been successful and accomplished. Rate the farmer group achievement is a token of appreciation for the combined group of farmers who have succeeded in improving the performance and productivity of agribusiness, so the farmer group motivated to further develop the business and function as the institutional main actors of agricultural development in rural areas[9]. (a). Gapoktan performance can be seen the fulfilment of the characteristics Gapoktan strong and independent. Farmers' groups combined strong and independent, is characterized among other things: (b). A meeting / conference members / board meetings are held regularly and continuously; (c). Formulation of a work plan gapoktan jointly and implemented by the executive in accordance with the collective agreement and the end of every execution, overall evaluation of participation; (d). Having rules/norms written agreed and adhered together. (e). Having a recording / administration of each member organization neat; (f). Facilitating commercial farming and market-oriented; (g). As a source of information and technology services to businesses of farmers in general and members of farmer groups in particular; (h). Their fabric of cooperation between Gapoktan with other parties; (i). Their fertilizing good business capital contributions of members or the preliminary results of operations / activities Gapoktan.

Institutional farmer in this case gapoktan formed so that rural agribusiness development program can succeed. Indicators of success include the success PUAP output, outcome and benefit income. Indicators of success output, among others: a. signals to aid to farmers, farm labourers and poor farm households Gapoktan members as capital to productive agricultural enterprises; and b. facilitating the implementation of capacity building and human resource capabilities Gapoktan manager, Extension and PMT. Outcome Indicators of success include: a. increased ability Gapoktan in facilitating and managing capital assistance for farmer members of both farmers tilling the owner, tenant farmers, farm labourers or farm household; b. increasing number of farmers, farm workers and farm households that receive venture capital assistance; and c. increased activity agribusiness activities (upstream, and downstream farming) in rural areas. While the benefits and Impact Indicators, among others: a. the development of agribusiness in rural areas; b. Gapoktan as an economic institution functioning of farmers in rural areas, which is owned and managed by farmers; and c. reduced the number of poor and unemployed farmers in rural areas [10].

LKM-A (Farmers Microfinance Institutions of Agribusiness) is an autonomous business unit founded and owned by the beneficiary BLM Gapoktan PUAP to resolve issues / constraints Gapoktan member PUAP access to capital; (a) In order for microfinance operations can take place properly, gapoktan directed to have the following capabilities: Develop creativity and initiative group union members to take advantage of information and access to the capital; (b) Increase the ability of member gapoktan to manage microfinance commercially; (c) Develop the ability Gapoktan members to explore the sources of business, which can increase capital; (d) Encourage and advocate gapoktan members that are willing and able to set aside the results of efforts to develop venture capital; (e) Encourage and advocate for member gapoktan so willing and able to perform activities of savings and loan in order to facilitate the development of venture capital.

By increasing the capacity LKMA is by itself the social capital will grow and strengthen, management and members gapoktan can be more responsible (trustworthy), obedient to the norms, have a good participation, have a good cooperation, good fellow members or managers or outsiders will increase the capacity LKMA. 


\section{RESEARCH MET HODOLOGY}

The research location determined by purposive namely in the city of Sukabumi which are urban areas that allegedly had faded social capital. The data taken is primary data and secondary data. Primary data from in-depth interviews using a questionnaire to Farmer's Supervisor (PMT) and Technical Team PUAP while secondary data derived from reports of performance PUAP Sukabumi. The information collected includes social capital and performance LKMA of gapoktan who get funding PUAP since 2008. The data collected were tabulated and analysed descriptively.

\section{FINDING \& DISCUSSIONS}

There are 8 gapoktan receiver PUAP 2008 in the city of Sukabumi, the results of research on the performance gapoktan is; member Lembursitu Gapoktan suboptimal adherence to agreements, Human Resources Farmers still need to be improved, reduced intensity of the meeting, the group leader's role is reduced, the perception of government funding is a grant and not have to be in to account. The resignation of senior officials for the elderly, PUAP activities are still going well, one of the main level of the city's best gapoktan Sukabumi. Participation gapoktan Situmekar member and chairman of the group is not good, the Chairman Gapoktan inactive, less current instalments repayment. PUAP activity is still running. Gapoktan Sindangsari, chairman of the group is not good. Diversion of funds by the chairman Gapoktan Rp. 27.5 million, refunds jammed in members, administrators are not compact, and yet have a secretariat, member participation bad, once visited by the inspectorate of Ministry of Agriculture, PUAP activity has stopped. Gapoktan Mekarjaya, the administrative less neat, good public participation, open secretariat 2 times a week, activities PUAP goes well. Gapoktan Daya Mandiri participation bad members, administrator's gapoktan weak, refund jammed, the participation of the head of the group was not good. Open secretariat erratic, PUAP activity has stopped, has been carried out by the Technical Team PUAP Monev State level. Gapoktan Mutiarajaya poor member participation, communication between the board does not run, the manager of LKM-A resigned without clearing duties in advance, a refund jammed and PUAP activity has stopped, the secretariat is not strategic, Gapoktan is already visited by the technical team in order to evaluate. Gapoktan Sakinah. Until now gapoktan still perform services to members despite the return of members of substandard, a sense of belonging to the group union members are still lacking, activities PUAP still running well. Gapoktan Mitra Utama, the role of the chairman of the group is not good, there is a delay instalment of farmers engaged in Food Plant PUAP activity is still running well, one of the main LKMA 3 provincial level best to Jabar.

From the above it can be seen that in the management of PUAP program, there are several issues of social capital associated with the performance gapoktan PUAP in Sukabumi. Among them are 1) member Gapoktan suboptimal adherence to an agreement (the norms / rules), especially for a refund, 2) lack of a sense of responsibility (confidence / trust), 3) the lack of communication and cooperation (networking).

The growth of social capital is seen as one way that can touch the root causes of poverty. Social capital has three basic elements which interact, namely networking, mutual trust and norms that can be used optimally in community empowerment. In this case PUAP is one of the innovations in poverty reduction programs [11]. This is in accordance with the opinion of Putnam, Bourdieu say Social capital is the aggregate of the actual or potential resources which are linked to possession of a durable network of more or less institutionalized relationships of mutual acquaintance recognition-in other words, to a membership in a group-which provides each of its members with backing of the collectivity-owned capital [12]. Social capital can be summarized as networking and social values that can facilitate the individual and the community to achieve common goals effectively and efficiently[13].

This social capital issues affect the performance LKMA PUAP which can be seen in the following table:

TABLE I. PERFORMANCE OF LKM-A

\begin{tabular}{|l|l|c|c|l|}
\hline No & Gapoktan & $\begin{array}{c}\text { Beginning } \\
\text { Asset }\end{array}$ & \multicolumn{1}{|c|}{$\begin{array}{c}\text { Aurrent } \\
\text { Asset }\end{array}$} & Explanation \\
\hline 1 & Lembursitu & 100.000 .000 & 190.022 .142 & $\begin{array}{l}\text { Well } \\
\text { performing }\end{array}$ \\
\hline 2 & Situmekar & 100.000 .000 & 122.529 .235 & $\begin{array}{l}\text { Worse } \\
\text { performing }\end{array}$ \\
\hline 3 & Sindangsari & 100.000 .000 & 106.797 .515 & $\begin{array}{l}\text { Problematic } \\
\text { performing }\end{array}$ \\
\hline 4 & Mekar Jaya & 100.000 .000 & 110.364 .000 & $\begin{array}{l}\text { Worse } \\
\text { performing }\end{array}$ \\
\hline 5 & $\begin{array}{l}\text { Daya } \\
\text { Mandiri }\end{array}$ & 100.000 .000 & 107.902 .900 & $\begin{array}{l}\text { Problematic } \\
\text { performing }\end{array}$ \\
\hline 6 & Mutiarajaya & 100.000 .000 & 103.525 .235 & $\begin{array}{l}\text { Problematic } \\
\text { performing }\end{array}$ \\
\hline 7 & Sakinah & 100.000 .000 & 123.891 .000 & $\begin{array}{l}\text { Worse } \\
\text { performing }\end{array}$ \\
\hline 8 & Mitra Utama & 100.000 .000 & 141.426 .750 & $\begin{array}{l}\text { Well } \\
\text { performing }\end{array}$ \\
\hline
\end{tabular}

From 8 gapoktan receiver PUAP 2008 in the city of Sukabumi only 2 LKMA which has good performance criteria for refund is classified as current. 3 LKMA criteria substandard and 3 LKMA criteria jammed. If it is associated with social capital LKMA managers / administrators and farmers Gapoktan gapoktan members of this condition with relatively low social capital. There are three parameters of social capital, trust (trust), norms (norms) and networks (networks). The results showed that trust in respect of the responsibility for the management and members gapoktan is low, too low adherence to norms and lack of cooperation / networking. Mutual trust (trust) is a growing expectation in society through behavior that want to cooperate, honest and consistent based on norms / rules that are shared by all citizens [14]. This is what causes the lack of performance LKMA. According to Putnam which states that social capital shows on networks, norms and trust that the potential productivity of society. However, social capital in contrast to financial capital, because of social capital are cumulative and grow by itself (self-reinforcing). Therefore, social capital will not be depleted if used, but increasing. The destruction of social capital is more often caused not by use, but because it is not used. To address the lack of social capital that is needed to strengthen social capital for management and members Gapoktan PUAP

Strengthening social capital for management and member's gapoktan can be done by increasing the capacity LKMA as follows; (a) Develop creativity and initiative group union members to take advantage of information and access to the capital; (b) Increase the ability of member gapoktan to manage microfinance commercially; (c) Develop the ability Gapoktan members to explore the sources of business, which can increase capital; (d) Encourage and advocate gapoktan members that are 
willing and able to set aside the results of efforts to develop venture capital; (e) Encourage and advocate for member gapoktan so willing and able to perform activities of savings and loan in order to facilitate the development of venture capital.

By increasing the capacity LKMA is by itself the social capital will grow and strengthen, management and members gapoktan can be more responsible (trustworthy), obedient to the norms, have a good participation, have a good cooperation, good fellow members or managers or outsiders will increase the capacity LKMA.

Increased ability LKMA this needs to be done with the strengthening of social capital for the management and members gapoktan LKMA. From the research results can be seen that the mutual trust, solidarity, adherence to the rules / norms has begun to fade. It is evident from the many LKMA who has bad credit. Even some officials who embezzled funds LKMA PUAP. Members and officials do not adhere to the rules / norms that exist. Strengthening social capital is very important because the dimensions of social capital emphasizes the togetherness in the community to achieve the purpose of improving the quality of life, so it needs the development of values that must be adhered to by its members such as: the attitude of participation, mutual attention, reciprocity and mutual trust that is mutual trust, solidarity, adherence to norms would reduce delinquency and administrators are not responsible. Strengthening networks network needs to be done with the concept of Triple Helix is the cooperation between the community, government and business world. Of clients or members Gapoktan LKMA can get funding from the profit sharing and savings of their members in the form of savings or voluntary savings. So the fund will develop and roll. Government support in the form of coaching and supervision is essential both through the Technical team PUAP, PMT and PPL. LKMA of the business world can access sources of funding that comes from the company's CSR fund.

\section{CONCLUSION \& SUGGESTIONS}

The result of this research showed social capital problems, as followed: 1) Gapoktan member adherence to the agreement (the norms/rules), especially for a refund, 2) Less of a sense of responsibility (confidence/trust), 3) Less of communication and cooperation (networking). Based on the social capital analyse, there are three categories of LKMA performance, there are LKMA well performing, worse and problematic performing. Strengthen of social capital to improve LKMA performance to solve their problems with increase capabilities of LKMA. This LKMA capability needs to be done with the strengthening of social capital for the management and member's gapoktan LKMA, namely mutual trust, solidarity, adherence to norms would reduce delinquency and administrators are not responsible. Strengthening networks network needs to be done with the concept of Triple Helix is the cooperation between the community, government and the business world, so LKMA able to access funding from the government or the company's CSR.

\section{REFERENCES}

[1] Ostrom, E. 1992. Crafting Institution, Self-Governing Irrigation Systems. San Fancisco;ICS Press.p 19.

[2] Coleman, J.S. 1988. Social Capital in the Creation of Human Capital. American journal of Sociology. p95-120.
[3] Putnam, R.D. 1993. Making Democracy Work Civic Traditions in Modern Italy. Princeton University Press. Princeton.p 167.

[4] Dhesi, Autar S. 2011. Social Capital and Community Development: An Analysis of Two Cases from India and Bangladesh. Journal of Asian and African Studies. Oxford University Press. p533-545

[5] Situmorang, Erlina, Munzilati, Asfi dan Kaluge, David. 2012. Modal Sosial dan Keberhasilan Pelaksanaan Program Pengembangan Usaha Agribisnis Perdesaan di Kabupaten Monokwari. Jurnal SEPA : Vol. 8 No.2 Pebruari 2012 : $104-115$. Fakultas Pertanian UNS. Surakarta.p104-115

[6] Supriadi, Dedy. 2013. Studi Tentang Kinerja Pegawai Puskesmas Kecamatan Sesayap Hilir Kabupaten Tana Tidung. Ejournal Pemerintahan Integratif. Ejournal.pin.or.id. p304-318.

[7] Mangkunegara, A.P. 2000. Manajemen Sumber Daya Manusia. Perusahaan. Bandung : PT Remaja Rosdakarya.p67

[8] Sulistiyani., A.T. 2003. Manajemen dan Sumber Daya Manusia : Konsep Teori dan. Pengembangan Dalam Konteks Organisasi Publik. Yogyakarta. Graha Ilmu.p223

[9] Peraturan Menteri Pertanian Nomor : 82/Permentan/OT.140/8/2013 Tanggal : 19 Agustus 2013 Tentang Pedoman Penumbuhan dan Pengembangan Kelompoktani dan Gabungan Kelompoktani.

[10] Kementrian Pertanian, 2015. Pedoman Umum Pengembangan Usaha Agribisnis Perdesaan (PUAP). Jakarta.

[11] Pramono, St. Agung Dwi. 2012. Pengaruh Modal Sosial Terhadap Kemiskinan Rumah tangga. JEJAK, Journal of Economics and Policy. Vol. 5 No.2. p.117-229

[12] Bourdieu, P.1986. "The Forms of Capital", in Richardson, J.(ed) Handbook of Theory and Research for Sociology of Educationn. New York; Greenwood Press. P. 242

[13] Annas Wibisono, Galih and Darwanto, D. 2016. Stratei Penguatan Modal Social Kelompok Tani Dalam Pengembangan Pertanian. JEJAK; Journal of Economics and Policy. Vol. 9 No.1. p.61-81.

[14] Fukuyama, F.1995. Trust, The Social Virtues and the Creation of Prosperity. New York. The Free Press.p.26. 